\title{
Isolation and Characterization of Clostridium stercorarium sp. nov., Cellulolytic Thermophile
}

\author{
ROBERT H. MADDEN \\ Agriculture and Food Bacteriology Research Division, Belfast BT9 5PX, Northern Ireland
}

\begin{abstract}
Clostridium stercorarium, a new species of anaerobic, sporeforming, thermophilic, saccharoclastic, cellulolytic bacteria, is described. The colonies produced by these bacteria on cellobiose agar are 3 to $6 \mathrm{~mm}$ in diameter, cream colored, glossy, and umbonate with flat, entire margins. Single cells are straight rods 0.7 to 0.8 by 2.7 to $7.7 \mu \mathrm{m}$, with oval terminal spores. Fermentation products from cellulose include hydrogen, carbon dioxide, ethanol, acetate, and lactate. The deoxyribonucleic acid base composition of the type strain of $C$. stercorarium, NCIB 11754, is $39 \mathrm{~mol} \%$ guanine plus cytosine, and its temperature optimum is $65^{\circ} \mathrm{C}$. The specific epithet refers to the source of the original isolate, rotting vegetation (a compost heap).
\end{abstract}

During studies of the cellulase complex of Clostridium thermocellum NCIB $10682^{\mathrm{T}}$ (type strain) (1), it was decided to obtain other thermophilic, cellulolytic isolates in order to compare their cellulase systems. Samples of decomposing vegetation were taken from a compost heap with an internal temperature of $69^{\circ} \mathrm{C}$.

A pure culture of a thermophilic, cellulolytic anaerobe was isolated, and analyses of its cellulase were performed. These studies showed that the new isolate produced significantly different enzymes than $C$. thermocellum (1a). Therefore, the new isolate was characterized, and the results are presented in this report.

\section{MATERIALS AND METHODS}

Media. The solid medium used in this study contained the following: $\mathrm{NH}_{4} \mathrm{SO}_{4}, 1.6 \mathrm{~g}$; yeast extract, 1.0 g; agar no. 3 (Oxoid Ltd., London, Great Britain), 30g; $\mathrm{K}_{2} \mathrm{HPO}_{4}, 1.65 \mathrm{~g}$; cysteine hydrochloride, $0.5 \mathrm{~g} ; \mathrm{NaCl}$, $0.96 \mathrm{~g} ; \mathrm{MgSO}_{4}, 96 \mathrm{mg} ; \mathrm{CaCl}_{2}, 96 \mathrm{mg}$; resazurin solution $(0.1 \%, \mathrm{wt} / \mathrm{vol}), 1 \mathrm{ml}$; cellulose suspension, $200 \mathrm{ml}$; distilled water, to 1 liter. The $\mathrm{pH}$ was adjusted to 7.2 with $5 \mathrm{M} \mathrm{NaOH}$.

The cellulose suspension consisted of $4 \%$ (wt/vol) Whatman CF11 cellulose powder ball-milled for $72 \mathrm{~h}$.

The broth medium had a similar composition, but the cellulose was provided as a strip $(4.5$ by $1.0 \mathrm{~cm})$ of Whatman no. 1 filter paper in each tube.

The solid medium was dispensed in tubes in 5-ml volumes, and the liquid medium was dispensed in 10$\mathrm{ml}$ volumes. All media were sterilized by autoclaving at $121^{\circ} \mathrm{C}$ for $15 \mathrm{~min}$.

Anaerobic culture methods. The anaerobic techniques of Hungate (5) were used throughout this study. Media in standard test tubes $(19$ by $150 \mathrm{~mm}$; Corning Glass Works, Corning, N.Y.) sealed with Suba Seal no. 29 closures (William Freeman Ltd., Barnsley, Great Britain) were used for the identification and selection of cellulolytic bacteria. Routine incubations were at $60^{\circ} \mathrm{C}$. Oxygen-free nitrogen was used as the atmosphere.

Isolation procedures. A 5-g sample of compost was added to $10 \mathrm{ml}$ of liquid medium and incubated for 10 days; $1 \mathrm{ml}$ of this preparation was subcultured in liquid medium and incubated until the filter paper strip showed signs of decay. Then $1 \mathrm{ml}$ was subcultured into fresh medium. The fifth subculture was serially diluted and inoculated into roll tubes. After 7 days of incubation, cellulolytic colonies were transferred to cellobiose medium by means of a bent Pasteur pipette (5). After 2 days subcultures ( $1-\mathrm{ml}$ inocula) were made into fresh cellobiose medium. These subcultures were incubated for 2 days and then serially diluted and inoculated into roll tubes. Subcultures (1-ml inocula) in liquid medium were also made. Culture purity was then assessed by microscopic examination and by examination of roll tubes for non-cellulolytic colonies.

Biochemical reactions. Biochemical characteristics were studied by the methods described by Holdeman et al. (4). The liquid medium described above was used as the basal medium during carbohydrate fermentation assays; to render the medium more sensitive to acid production, only $1 \mathrm{~g}$ of $\mathrm{K}_{2} \mathrm{HPO}_{4}$ per liter was used.

Deoxyribonucleic acid base composition. Deoxyribonucleic acid was isolated, and its melting temperature was determined as described by $\mathrm{Ng}$ et al. (7). The guanine-plus-cytosine content of the deoxyribonucleic acid was calculated by using the equation of De Ley (2). A culture of $C$. thermocellum NCIB $10682^{\mathrm{T}}$ was used as a standard.

Fermentation end product analyses. Fermentation end product analyses were performed as previously described (6).

Morphology. Living and stained cells were examined by light microscopy. Cell size was determined by using nigrosin stain (3). For electron microscopy an overnight culture grown in cellobiose broth was harvested by centrifugation at $1,700 \times g$ (average) for 20 min. The pellet was suspended in distilled water and centrifuged as before. This washing procedure was repeated twice. The suspension of washed cells was 

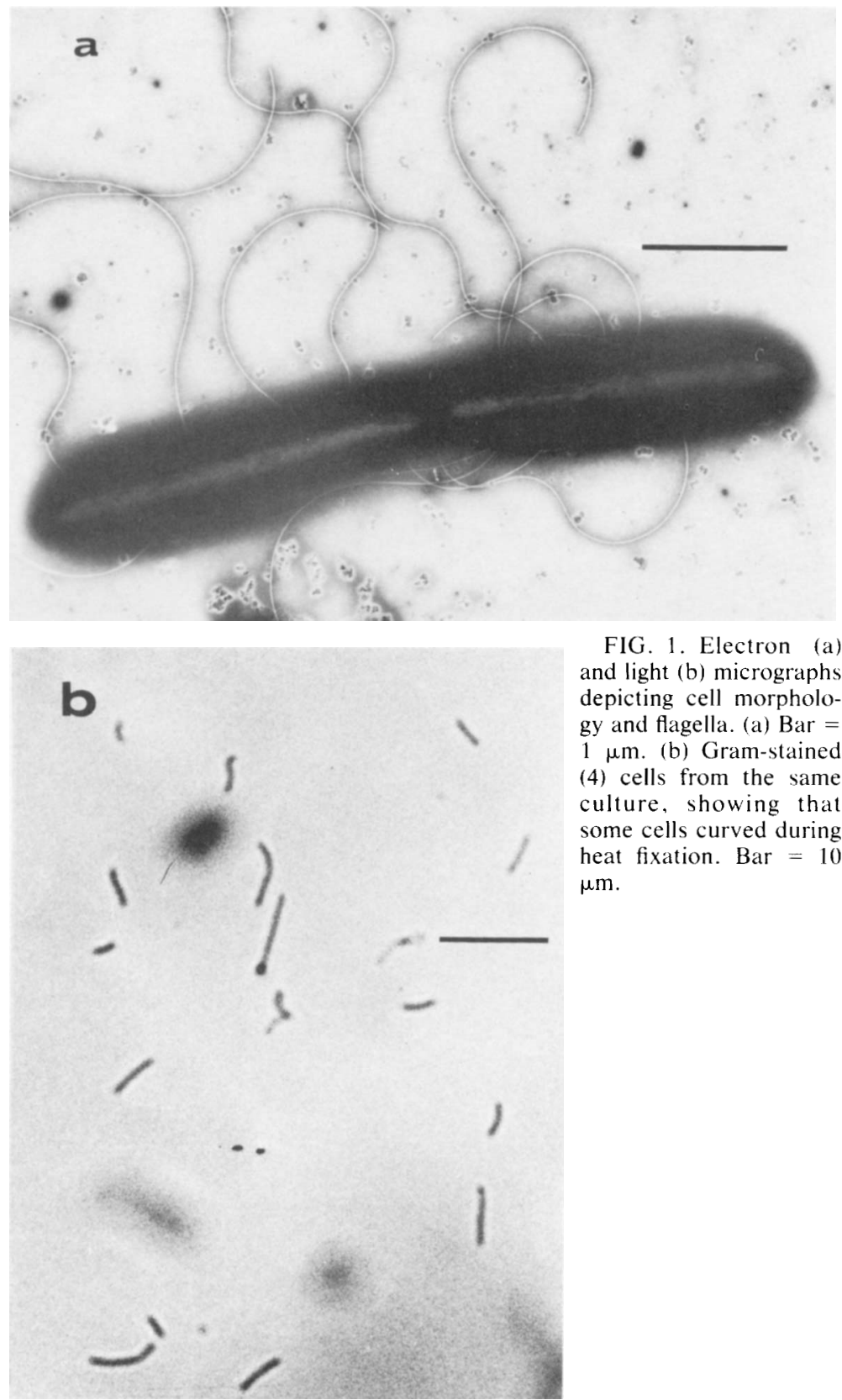

FIG. 1. Electron (a) and light (b) micrographs depicting cell morphology and flagella. (a) Bar = $1 \mu \mathrm{m}$. (b) Gram-stained (4) cells from the same culture, showing that some cells curved during heat fixation. Bar $=10$ $\mu \mathrm{m}$.

diluted 1 to 10 with stain $(2 \%$ [wt/vol] phosphotungstic acid) and viewed on carbon-coated grids with an AEI type 801 electron microscope.

Growth rate and temperature for optimal growth. Growth rate and temperature for optimal growth were determined by assaying for cell protein as previously described (5).

Lactate determination. Lactate was determined by using the gas chromatographic method of Holdeman et al. (5).

\section{RESULTS AND DISCUSSION}

The enrichment and selection procedures yielded a pure culture of an obligately anaerobic, sporeforming bacterium with characteristics consistent with those of the genus Clostridium (9). This bacterium is an obligate thermophile and degrades cellulose but is different from $C$. thermocellum, the only other thermophilic and 
cellulolytic clostridium that has been described and officially recognized (8). Therefore, I propose a new species, Clostridium stercorarium, with the characteristics given below.

Clostridium stercorarium sp. nov. (L. adj. stercorarium pertaining to dung, referring to the source of the isolate, a compost heap). Cells are straight rods 0.7 to 0.8 by 2.7 to $7.7 \mu \mathrm{m}$ and are motile and peritrichous (Fig. 1). Endospores are oval and terminal. Vegetative cells decolorize readily and usually stain gram negative.

Colonies in cellulose agar are lenticular, unpigmented, and 1 to $2 \mathrm{~mm}$ in diameter. After incubation for 7 days, colonies are surrounded by clear zones, representing cellulose hydrolysis, that usually are 3 to $5 \mathrm{~mm}$ in diameter. Upon continued incubation the colonies become cream colored.

Surface colonies on cellobiose agar are 3 to 5 $\mathrm{mm}$ in diameter, glossy, not pigmented, and umbonate. The raised centers of the colonies are cream colored, and the margins are flat, entire, and colorless.

Optimum growth is obtained at $65^{\circ} \mathrm{C}$ and near $\mathrm{pH} \mathrm{7.3.} \mathrm{Growth} \mathrm{at} 60$ or $70^{\circ} \mathrm{C}$ is approximately $60 \%$ of that obtained at $65^{\circ} \mathrm{C}$. The mean generation time for cultures grown in cellulose broth at $65^{\circ} \mathrm{C}$ is $16 \mathrm{~h}$.

Only slight growth occurs in nutrient broth without fermentable carbohydrate. With a fermentable carbohydrate cultures are moderately turbid, with a smooth sediment. The $\mathrm{pH}$ of cellobiose broths is 4.8 after incubation for 2 days.

Other characteristics of the species are given in Table 1. The mean $\mathrm{pH}$ of uninoculated media was 6.81 . The mean $\mathrm{pH}$ of the media considered not to have been fermented was 6.62 , the reduction in $\mathrm{pH}$ probably being due to the fermentation of cellobiose transferred with the inoculum. A value of $\mathrm{pH} 6.0$ was chosen to indicate growth, and the mean $\mathrm{pH}$ of cultures showing growth was 5.77; hence, growth was indicated by a decrease in $\mathrm{pH}$ of approximately $0.8 \mathrm{U}$.

Fermentation products in glucose broths were ethanol, acetate, lactate, hydrogen, and carbon dioxide. About $4 \mathrm{mM}$ acetate, $4 \mathrm{mM}$ ethanol, and less than $1 \mathrm{mM}$ lactate were found in typical cultures.

Endoglucanase, exoglucanase, and xylanase are produced in cellulose broths (1a). Approximately $60 \%$ of the endoglucanase activity is produced after growth has ceased (J. -F. Berenger and $\mathrm{N}$. Creuzet, unpublished data).

Isolated from a compost heap.

The guanine-plus-cytosine content of the deoxyribonucleic acid is $39 \mathrm{~mol} \%$ as determined by the melting temperature method.

The type strain is National Collection of Industrial Bacteria strain NCIB 11754.
TABLE 1. Reactions of $C$. stercorarium and $C$. thermocellum

\begin{tabular}{lcc}
\hline Fermentation of: & $\begin{array}{c}\text { C. stercorarium } \\
\text { NCIB } 11754^{7 \%}\end{array}$ & $\begin{array}{c}\text { C. thermocellum } \\
\text { NCIB } 10682^{?}\end{array}$ \\
\hline Amygdalin & $-{ }^{b}$ & + \\
Arabinose & + & - \\
Galactose & + & - \\
Glycogen & + & - \\
Lactose & + & - \\
Maltose & + & - \\
Mannose & + & - \\
Melibiose & + & - \\
Rhamnose & + & - \\
Ribose & + & - \\
Starch & + & - \\
Xylose & + & \\
\hline
\end{tabular}

${ }^{a} \mathrm{~T}=$ type strain.

${ }^{b}+, \mathrm{pH}$ below 6.0. Both strains ferment cellobiose, cellulose, esculin, glucose, and salicin. Neither strain ferments adonitol, dulcitol, erythritol, fructose, glycerol, inositol, inulin, mannitol, melezitose, raffinose, sorbitol, sorbose, sucrose, or trehalose. Neither strain produces lecithinase, lipase, $\mathrm{H}_{2} \mathrm{~S}$, urease, or acetylmethylcarbinol. Neither strain reduces nitrate or sulfate, liquifies gelatin, or grows in litmus milk.

Differentiation from the type strain of $C$. thermocellum (NCIB 10682), the only other described species of Clostridium that is thermophilic and cellulolytic. In cultures of $C$. thermocellum, both the colonies and the surrounding area representing cellulose hydrolysis are yellow. This strong pigmentation was not observed in and around colonies of $C$. stercorarium. Also, $C$. thermocellum grows much faster (generation time, approximately $7 \mathrm{~h}$ ) on cellulose (7) than does $C$. stercorarium, probably due to the lower production of exoglucanase by $C$. stercorarium.

$C$. thermocellum ferments mainly cellulose, and $C$. stercorarium ferments hemicelluloses solublized by its endocellulase, exocellulase, and xylanase (Table 1).

Creuzet and Frixon (1a) found that $C$. stercorarium produces more endoglucanase and less exoglucanase (ratio, 20:1) than $C$. thermocellum. There was no measurable endoglucanase activity in cultures of $C$. stercorarium until the middle of the log phase of growth (Berenger and Creuzet, unpublished data), whereas in cultures of $C$. thermocellum endoglucanase production parallels the growth of the organism. Also, Creuzet and Frixon (1a) found that $C$. thermocellum does not produce a xylanase, as does $C$. stercorarium. Since $C$. thermocellum does not ferment pentoses (3), it would not be expected to possess a xylanase.

\section{ACKNOWLEDGMENTS}

I thank Nicole Creuzet for advice and encouragement during this work and Jean-Francois Berenger for permitting 
me to publish his results concerning endoglucanase production.

Part of this work was performed during the tenure of a grant from Scientific and Technical Education Directorate of the Commission of the European Communities.

\section{LITERATURE CITED}

1. Ait, N., N. Creuzet, and P. Forget. 1979. Partial purification of cellulase from Clostridium thermocellam. J. Gen. Microbiol. 113:399-402.

1a.Creuzet, N., and C. Frixon. 1983. Purification and characterisation of an endoglucanase from a newly isolated thermophilic bacterium. Biochimie 65:149-156.

2. De Ley, J. 1969. Reexamination of the association between melting point, buoyant density, and chemical base composition of deoxyribonucleic acid. J. Bacteriol. 101:738-759.

3. Gomez, R. F. 1980. Prospect of conversion of cellulosic biomass to ethanol by thermophilic clostridia, p. 177-183. In Colloque Cellulolyse Microbienne. ATP and PIRDES, Marseille.
4. Holdeman, L. V., E. P. Cato, and W. E. C. Moore (ed.). 1977. Anaerobe laboratory manual, 4th ed. Anaerobe Laboratory, Virginia Polytechnic Institute and State University, Blacksburg.

5. Hungate, R. E. 1969. A roll tube method for cultivation of strict anaerobes. p. 117-132. In J. R. Norris and D. W. Ribbons (ed.), Methods in microbiology, vol. 36. Academic Press, Inc., London.

6. Madden, R. H., M. H. Bryder, and N. J. Poole. 1982 Isolation and characterization of an anaerobic, cellulolytic. bacterium. Clostridium papyrosolvens sp. nov. Int. J. Syst. Bacteriol. 32:87-91.

7. Ng, T. K., P. J. Weimer, and J. G. Zeikns, 1977. Cellulolytic and physiological properties of Clostridium thermocellum. Arch. Microbiol. 114:1-7.

8. Skerman, V. B. D., V. McGowan, and P. H. A. Sneath (ed.). 1980. Approved lists of bacterial names. Int. J. Syst. Bacteriol. 30:225-420

9. Smith, L. DS., and G. Hobbs. 1974. Genus III. Clostriditum. p. 551-572. In R. E. Buchanan and N. E. Gibbons (ed.) Bergey's manual of determinative bacteriology, 8 th ed. The Williams \& Wilkins Co., Baltimore. 